\section{Chairman of the board: demographics effects on role pursuit}

Demographics effects on role

pursuit

\author{
Northampton Business School, The University of Northampton, \\ Northampton, UK, and \\ Andrew P. Kakabadse \\ Cranfield School of Management, Cranfield, UK
}

Received 1 December 2005

Revised 4 April 2006

Accepted 3 July 2006

\begin{abstract}
Purpose - This paper aims to undertake a study of national configurational demographics in order to determine the spread of understanding of the chairman's role, performance and contribution.

Design/methodology/approach - Qualitative methodology, exploratory in nature through in-depth interviews and workshop discussion involving 103 UK, US and Australian participants, was undertaken.

Findings - The role of chairman is considered as having a distinct effect on board dynamics, role and contribution and the monitoring and support of management. Nine demographic factors are identified as affecting the manner in which the role of chairman is exercised in the UK, USA and Australia.

Research limitations/implications - The findings of this qualitative exploratory study need to be integrated into a quantitative empirical survey in order to ascertain the validity of the results to date.

Practical implications - The two key conclusions highlight the requirement for governance due diligence, examining the financial and competitive strength of the organisation as well as uncovering contextual sensitivities.

Originality/value - Insufficient attention has been given to the role of chairman. The study offers additional insight on how demographic factors influence the shaping and determination of the role of chairman. This paper should be of interest to practitioners, consultants, line managers, board members, chairmen, management academics and business studies students.
\end{abstract}

Keywords Chairmen, Demographics, Boards, Management roles, Senior management, Non-executive directors

Paper type Research paper

The authors offer deepest thanks to Lord Tom Sawyer, House of Lords, UK, who has been powerfully instrumental in negotiating access to British chairmen and chief executive officers (CEOs) for the purpose of research. Also, warmest thanks to Ellen Van Velsor, Center for Creative Leadership, North Carolina, USA, for having made possible interviews with some of America's top chairmen and chief executives. Similar thanks to Keith Niblett and colleagues at Thunderbird School of Business, Phoenix, Arizona for having made available top US managers and board members for interview. Special mention is made of Kate Donaghy, Manchester Square Partners, entrepreneur, counsellor and one who is accomplished at placing the most capable of executives in the most demanding of jobs, in providing for access to some of the UK's finest top managers. In similar vein, David Pumphrey, Partner, Heidrick and Struggles, Australia, with his insight and understanding of the Australasian corporate boardroom, not only provided access to a unique group of top business leaders in Australia but also offered advice invaluable to the success of this study. Thanks also to Ruth Barratt for testing the authors' initial findings with UK and US board members.

Most of all, the authors are deeply indebted to Severstal, the Russian Steel company, who have sponsored and financially supported the research reported in this paper. Severstal's devotion to promoting learning acts as an example of what are the characteristics of a world class company.

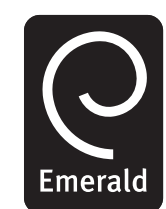

Journal of Management Development

Vol. 26 No. 2, 2007 pp. 169-192

(C) Emerald Group Publishing Limited 0262-1711 
$\mathrm{JMD}$

26,2

170

Arising as a counter to US and UK corporate corrupt practice of the 1980s and 1990s, greater attention to governance protocols introduced discipline to board processes and procedures in order to safeguard the interests of the shareholders of the enterprise. Either as a result of legislation or "voluntary" code emanating from securities commissions, stock exchanges, investors associations as well as supranational organisations (OECD, 1999), and despite variance in scope and detail, boards are increasingly being required to display attentiveness to four fundamental principles of governance (Coombes and Wong, 2004), namely:

- the upholding of shareholder rights;

- clarity of accountability for both the board and management which, in turn, has spawned greater attention to the role, purpose and contribution of both entities;

- the accuracy, transparency and timeliness of financial and non financial reporting; and

- attendance to the interests of minority shareholders and other pertinent stakeholders.

As a result, the enterprise is required to provide a financial return on shareholder investment, which commentators as Kay and Silbertson (1995) point out, is the sole purpose of the publicly quoted company. Thus, two counter balancing pressures are prevalent on the board of the Anglo-American enterprise, the realising of profit for shareholders involving the exercising of governance disciplines for the protection of shareholder rights, and the nurturing of a proactive business culture for the purpose of financial and reputational gain. The juggling of interests to achieve both ends falls on the shoulders of the chairman of the board, a position that has reached public prominence as much due to the popular emergence of corporate governance (Hanson and Song, 2000; Kakabadse et al., 2006).

\section{Governance, controls and the chairman}

The requirement for profitability within the Anglo-American governance model of dispensed shareholder ownership within a liquid capital market while simultaneously promoting shareholder rights, has introduced two mechanisms of control over the affairs of the corporation; internal and external (Kakabadse and Kakabadse, 2001). The internal control mechanism is exercised through the one-tier board, composed of executive and non executive directors in the UK and Australian context and that of "outside" directors in the USA, who are recognised as independent or "grey" directors that have a close but indirect relationship with the firm (Hanson and Song, 2000). The long standing and still unchallenged contribution of each board director is to represent shareholders, namely the owners of the corporation, by holding accountable the management of the enterprise (Berle and Means, 1932).

External control consists of market forces such as distinct competitive factors in particular markets, developments in capital markets and labour markets, with the exercise of control being totally in the remit of professional management (Berle and Means, 1932; Jensen and Meckling, 1976). In themselves, market based competitive factors are considered to play a critical monitoring role as far as the company's performance is concerned (Berle and Means, 1932). For example, under-performing firms become an easy take-over target, often resulting in management and the board 
being replaced by the acquirer (Monk and Minow, 2004). Additionally, competitiveness in the labour market, especially in the executive recruitment market is significant in terms of external control as it is challenging for a declining company to attract high performing talent at a time when such talent is most needed (Monk and Minow, 2004).

Prior to the emergence of the governance movement, each shareholder in possession of a majority or minority holding, when concerned about firm performance or reporting issues, would more likely "vote with their feet" (sell their shares) than actively participate in exercising their rights, such as the monitoring and dismissal of management. A simple cost-benefit analysis of the day showed "it is not worth it", it being to, "exercise ownership rights and become involved in the affairs of the enterprise for that would incur the total cost of intervention for only a pro rata share of the gains, and even then if there is any" (Monk and Minow, 2004). Thus, managers were left considerably free to adopt an "oligarchic" presence and style. One role in particular has, and continues to have, the potential to allow its incumbent to behave in an aloof and unchecked manner, and that is that of the chief executive officer (CEO). The CEO role is a full-time post, embracing the responsibility for the day-to-day running of the company and for the setting (for most corporations) and implementing of corporate strategy (Cadbury, 1992; Dahya and Travlos, 2000; Weir and Laing, 2001). The long established practice of including the CEO on the corporate board is to allow board members direct access to this critical officer for the purposes of holding him/her accountable for the performance of the firm and for communicating progress towards the realisation of strategic and operational goals (Gioia and Chittipeddi, 1991, p. 442; Gioia and Thomas, 1996; Ward, 1996).

With the recognition that an unrestrained CEO and his/her team were a prime root of corporate excess, the role of chairman in UK and Australian companies was elevated to the role of the "keeper of the board" and also the "minder of the CEO" (Kakabadse et al., 2006). The monitoring of management by the non executive directors (NEDs) and the holding of the $\mathrm{CEO}$ accountable by the chairman allowed boards to gain a greater role in strategy formulation, providing independent judgement on senior executive appointments and determining performance related rewards. Thus, whether part-time, full-time, executive or non executive, emphasis has increasingly been placed on the chairman's effective leadership of the board as well as the "mentoring" of the CEO and executive management (Cadbury, 1992; Dahya and Travlos, 2000; Weir and Laing, 2001). According to Cadbury (1992), chairmen hold the responsibility of stewarding boardroom affairs by, for example, ensuring that non executive directors are in receipt of relevant information for board meetings (as well as any other pertinent company information) as well as to audit the affairs of the firm and determine the structure of remuneration for its senior full-time officers. In order to maintain impartiality, Cadbury (1992), and Higgs (2003) a decade later, argued that chairmen should be distanced from day-to-day company operations.

However, the downside to improved corporate governance is the simultaneous emergence of "regulation creep" as, the UK's Combined Code (Higgs, 2003) recommends 82 provisions for board adoption, which is a substantial increase of protocol to that recommended by Cadbury (1992). A number of commentators complain that the greater attention to governance processes has over-emphasised the "comply" side of the "comply and explain" duality of governance, moving to a principle of "comply or breach", thus positioning corporate governance as a tick box exercise
Demographics effects on role pursuit

171 
$\mathrm{JMD}$

26,2

172

rather than a deeper analysis of managerial and corporate practice (Coombes and Wong, 2004). The drift to compliance, as opposed to investigation and understanding, has even further elevated the stature of the role of chairman. Partly to ensure that the "tick box" mentality does not emerge but also to facilitate exploration of key enterprise issues framed as "strategies", "change", "goals", "competitiveness", "risk", "opportunities" and so on, the chairman is now viewed by an increasing number of commentators as holding equal status to that of the CEO (Kakabadse et al., 2001). With such a breadth of responsibility and influence, it is recognised that a chairman should not replicate the previous excesses of CEOs but instead attain consensus among board members by facilitating inclusive decision-making processes and drawing on board members' wealth of experience in terms of market and environment scanning and interpretation (Weick and Roberts, 1993). In ascertaining the nature of effective decision processes, two UK based studies, consisting of 134 chairmen in the first instance and 300 in the second (Dulewicz and Herbert, 1999, 2004), found no evidence that chairmen or board members believed that voting is a healthy manifestation of board decision-making, emphasising instead the merging of interests towards a "collective mind" (Lonergan, 1957). Parker (1990) agreed, positioning the role of chairman as that of looking outward and forward, a "leader-chairman", while the CEO manages the day-to-day affairs of the firm. Similarly, Garratt (1999, p. 29) names the chairman the "boss of the board" whose role is to "induct, include and train to competence each director and the board as a collective whole", a view with which others concur (Roberts, 2002; Austin, 2005). Roberts (2002) argues that the chairman is key to ensuring that boards play a "complementary" role to the CEO in the direction and control of the company, whatever their particular combination of duties and activities. In so doing, the CEO has an invaluable set of additional resources to draw on. The sensitive inter linkage between the role of chairman and CEO is further illustrated by the Florou (2005) eight year study concluding that a prime function of chairman is the dismissal of failing CEOs. Cognisant of the ever growing importance of chairmen, the Australian Shareholders' Association (ASA, 2004) guidelines suggest that the workload and the duty of the chairman are three times that of ordinary boardroom directors, requiring the role holder to allow for a minimum commitment of 360 hours (or 45 working days) per year. The ASA also concluded that any individual who sits on more than five boards is offering a disservice to each of the company's shareholders (ASA, 2004; Galacho, 2004).

On the basis that the chairman of the board has become, and has been recognised to become, ever more critical to the sustainable future of the firm, this paper explores the nature of the chairman's role and practice (Cutting and Kouzmin, 2004). A review of the interpretations of the role, responsibilities and contribution of the chairman, contrasting UK and US practice, precedes reporting the results of an international, qualitative survey of the demographic influences determining the role and practice of US, UK and Australian chairmen. Challenged is the assumption that the role of chairman is universally comparable. Scrutinised are certain configurational factors that are considered to provide shape to the role of chairman, parameters within which each incumbent determines the 'finer' nature of their role. The paper concludes that nationally determined configurational demographics influence the identity and boundaries of the role of chairman, thus calling into question whether the position of chairman can be considered as a universal managerialist concept. 


\section{Chairman: role in context}

Most pundits concur that with the ever greater demand for effective governance and transparency, the quality and capabilities of the chairman are critical to the performance of the board and, in turn, the enterprise (Kakabadse et al., 2001). A summary of recent studies outlining the characteristics of high performing chairmen is provided (Table I).

In determining the nature of the skill set of the chairman, considerable research has linked the performance effectiveness of the board to the quality of boardroom dynamics (Kakabadse and Kakabadse, 1999). The chairman's skill in managing often complex and sensitive relationships, with board directors expressing differences of view on strategy while striving to attain meaningful consensus on board and enterprise wide issues, is viewed as fundamental to the long-term future of the firm (Cadbury, 1992; Taylor, 2001).

The relational skills to lead through complex boardroom interactions, mindful of respecting and yet being assertive with critical board members such as the CEO, displaying a maturity of temperament in order not to appear as threatening to other

\begin{tabular}{|c|c|c|}
\hline Author & Study type & Characteristics of high performing chairman \\
\hline Parker (1990) & Qualitative study & $\begin{array}{l}\text { Outward looking } \\
\text { Forward looking }\end{array}$ \\
\hline Stewart (1991) & $\begin{array}{l}\text { Longitudinal qualitative } \\
\text { study of } 20 \text { GMs and } \\
\text { chairmen in the NHS (UK) }\end{array}$ & $\begin{array}{l}\text { Interdependent, complementary - partnership } \\
\text { with CEO } \\
\text { Balancing activities among key figures }\end{array}$ \\
\hline Cadbury (1992) & Experiential practice (UK) & $\begin{array}{l}\text { Leadership of the board } \\
\text { External face of the company (e.g. investors) }\end{array}$ \\
\hline Garratt (1999) & Experimental practice & $\begin{array}{l}\text { Boss of the board } \\
\text { Designee and chair of the board's } \\
\text { meetings/activities } \\
\text { New board member induction } \\
\text { Competency development of board members } \\
\text { Promotes board development }\end{array}$ \\
\hline $\begin{array}{l}\text { Kakabadse et al. } \\
\text { (2001) }\end{array}$ & $\begin{array}{l}95 \text { directors ( } 35 \text { in-depth, } \\
\text { semi-structured interviews } \\
\text { and three focus groups of } 20 \text { ) } \\
\text { NEDs/Chairmen, CEOs - } \\
\text { FTSE } 100 \text { (UK) }\end{array}$ & $\begin{array}{l}\text { Maturity } \\
\text { Relational skills } \\
\text { High political and social competence } \\
\text { Meetings skills } \\
\text { Coaching skills } \\
\text { Effective management of boardroom dynamics }\end{array}$ \\
\hline Roberts (2002) & $\begin{array}{l}35 \text { interviews with chairmen, } \\
\text { CEOs and NEDs (UK) }\end{array}$ & $\begin{array}{l}\text { Minimal ambition for executive power } \\
\text { Complementary to CEO (i.e. supporting role of } \\
\text { executive) in: } \\
\text { skills } \\
\text { experience } \\
\text { knowledge } \\
\text { temperament } \\
\text { business focus, or } \\
\text { values } \\
\text { Chairs meetings (e.g. focusing, stimulating } \\
\text { discussion, generating openness, trust) } \\
\text { Dismissing/appointing CEO }\end{array}$ \\
\hline
\end{tabular}

\section{Demographics effects on role pursuit}

173 
$\mathrm{JMD}$

26,2

174

board members and executive management and facilitating open communication, have emerged as the key elements of effective chairmanship (Roberts, 2002).

However, despite broad consensus from Anglo-American based studies of the skill set of chairmen, national demographic differences have equally been identified as determining the nature and responsibility span of chairmen. It is common practice in the UK and Australia for the role of chairman to be separated from that of CEO. The UK's Code of Best Practice, initially formulated through Cadbury (1992), recommended that the functions of CEO and chairman of the board should be split, with the chairman being responsible for the leadership of the board and for acting as the external face of the company, particularly in relation to investors. Through such division of responsibilities, no one individual emerges with unfettered power over the firm's strategic and operational decisions (Cadbury, 1992; Higgs, 2003). The effect of Cadbury was significant. The percentage of UK firms adopting separation of roles increased from 48.4 per cent in 1985 to 90.2 per cent by 1995 (Hanson and Song, 2000). By 2003, 1,689 chairman posts of 1,702 listed companies were held by executive or non executive board directors but not by the CEO (Higgs, 2003). In the same year, of the FTSE 100 companies, only five reported joint chairman/CEO roles while 24 chairmen were formerly the CEO of the same company (Higgs, 2003).

The UK's self-regulatory model of governance makes the chairman ultimately accountable for the activities and personnel of the corporation, particularly as UK company law draws no distinction between the responsibilities of executive and non executive directors (DTI, 2000). Similar to the UK Westminster model of government where the Prime Minister acts as "first among equals", shaping both the Cabinet and Parliament, the chairman, irrespective of being externally appointed or elected from within the board, occupies a similarly critically influential role within the board and across executive management. The Cadbury Code (Cadbury, 1992) and consequent corporate governance codes and reports, such as the Hempel (1998) report, emphasised that all directors are equally responsible for developing and implementing the company's strategy as well as for attending to the governance of the company. Thus the motto "one for all and all for one (un pour tous, tous pour un)", traditionally associated with the King's Musketeers (royal guards) captured in the 1844 French novel by Alexandre Dumas (1844/1992), is a useful analogy of statement of solidarity between the members of the board as well as between them and executive management. Supportive of the "team bonding" theme, it was the Higgs (2003) report that emphasised the pivotal role of chairman in crafting the conditions for director and board effectiveness. Higgs (2003) recommended that the chairman should be responsible for:

- the leading of the board, ensuring its effectiveness and for setting its agenda;

- ensuring the provision of accurate, timely and clear information to directors;

- ensuring for transparent and relevant communication to shareholders;

- arranging for the regular evaluation of the performance of the board, its committees and individual directors;

- enhancing the contribution of non executive directors; and

- ensuring for constructive relations between executive and non executive directors. 
In order to maintain the spirit of role separation, an emerging UK based trend is to recruit the chairman from existing non executive positions and not migrate the CEO to the position of chairman (Kakabadse et al., 2006). In fact, Higgs (2003, p. 81) specifically suggested that the "chief executive should not go on to become chairman of the same company" (Table II). The Higgs (2003) view is that a chairman, independent of immediate executive concerns, is more likely to provide objective opinion on proposals, be more effective in monitoring decisions and be more likely to promote shareholder interests (Weir and Laing, 2001). Thus, the critical and central nature of the role of chairman in the UK is considered as one of great prestige and the pinnacle of a successful career, likely facilitating access to government commissions, to boards of charities or other "worthy" social entities. Remuneration, however, is often only 10 to 20 per cent of that of the CEO (Coombes and Wong, 2004). That being said, the average UK non executive chairman's pay varies considerably. A survey of 33 boards by Pass (2004) found that the spread of non executive chairmen remuneration varied between $£ 125,000$ in Northern Foods Ltd. to $£ 480,000$ at Vodafone, with the average for internationally renowned companies emerging at $£ 222,000$.

Emphasised is the attention that needs to be given to maintaining a positive and supportive relationship between that of chairman and CEO (Westphal, 1998; Meyer, 2000; Kakabadse et al., 2001). Recognising that the role and contribution of chairman varies according to each corporate context, UK based studies (Stewart, 1991; Pettigrew, 1992; Kakabadse et al., 2001; Roberts, 2002) have concluded that the relationship

\begin{tabular}{lll}
\hline Context & UK & USA \\
\hline $\begin{array}{l}\text { Governance } \\
\text { practice }\end{array}$ & $\begin{array}{l}\text { Self regulatory (“comply or } \\
\text { explain” approach) }\end{array}$ & Legislation driven
\end{tabular}

$\begin{array}{ll}\text { Legal } & \text { "Collective responsibility" } \\ \text { responsibility } & - \text { "no difference" between } \\ & \text { executive and } \\ & \text { non-executive directors } \\ & \text { (shared liability) }\end{array}$

Role Clear preference for

separation separation (92 per cent of UK's 1,702 listed companies)

Independent At least one half of the directors
Australia

Self-regulation but strictly conforming to national regulatory authorities (Australian Securities and Investments Commission; Securities and Exchange Commission)

Chair has ultimate accountability

Clear preference for separation (90 per cent of 1,774 Australian listed companies)

Substantial majority of the board - often all, with exception of $\mathrm{CEO}$
Chairman/CEO and CFO

(chief financial officer) carry legal responsibilities - certification of financial reports under Sarbanes-Oxley (2002) Role duality. Only approximately 20 per cent of US's 6,703 listed companies have split chair/CEO roles

Substantial majority of the board (both independent and grey) - often all, with exception of CEO (NYSE Conference Board, New York Stock Exchange, 2003)
Demographics effects on role pursuit

175
Table II.

National variance of governance 
$\mathrm{JMD}$

26,2

176 between the chairman and CEO is critical to the sustainable future of the firm, irrelevant of the diversity and magnitude of challenges they both, and the organisation, face. Even studies of 40 years ago (Hodgson et al., 1965) observed the "complementarity of functions" between chairman and CEO, with Stewart (1991) stating that the chairman role and executive director's role within the context of the UK's health services, are mutually inter-dependent. Kakabadse et al. (2006), in their recent study of $\mathrm{CEO} /$ chair interrelations, reveal that the chair/CEO complementarity resembles a "generative dance" of constant attention to changes of mood and circumstance and, above all, the observable display of trust and respect for the other.

Despite the few studies of chairmen conducted in Australia, emerging evidence indicates comparability with UK practice, where chairman and CEO roles are separate with both reporting to boards predominantly consisting of non executive directors (Nicholson and Kiel, 2004; Table II). The Australian Securities and Investment Commission (ASIC) requires that chairman/CEO roles should be separated but in the few circumstances where the two are combined, an independent non executive director be appointed as the deputy chairman, who would act as the voice of independent reason (Bosch, 1995). For Australian boards, the chairman is recognised as the lead director determining the board agenda, undertaking public relations responsibilities and ensuring that board meetings run smoothly (Nicholson and Kiel, 2004). The chairman is also identified as the driving force behind board evaluation, facilitating the development of board directors, executive management and particularly that of the CEO (Nicholson and Kiel, 2004).

In contrast, to both the UK and Australia, role separation is not broadly observed in the USA whereby the roles of CEO, president and chairman are all one for the majority of the 6,703 publicly listed US companies whose stock is actively traded on the New York Stock Exchange (Wilshire Mutual Funds, 2005). Approximately 20 per cent of the Standard and Poor 500 companies have separated the role of chairman and CEO/president (Ward, 1996; Coombes and Wong, 2004; Table II). Within the American system, ultimate power lies with the role of president/chairman/CEO, while all other corporate actors fundamentally exist to assist the chairman/CEO/president to realise his/her goals and vision (Cutting and Kouzmin, 1998). Thus it is the $\mathrm{CEO} /$ president/chair who sets the agenda and determines the quantity, quality and timing of information for the board (Monk and Minow, 2004). Legal, financial accountability and probity lie with the combined role of chair/CEO and CFO (Ward, 1996; Table II).

Role duality has given licence to the chairman/CEO/president to carve and shape the corporation into a structure uniquely fitted to their personality and goals (Ward, 1996, p. 112). Not surprising therefore that US management and leadership literature has focused on the image of the strong chairman/CEO/president, wielding power to reallocate resources, exercising their personal influence to motivate others to achieve their goals and building a vision of the corporation's future that is inspirational and shared with enthusiastic followers (Kakabadse and Kakabadse, 2001). The US leadership literature paints a picture of preference to be led by a visible, dominant and powerful "supreme commander", or hero figure, representing American values and reflecting a personalised and idiosyncratic influence on the board of the US corporation (Garratt, 2003; Monk and Minow, 2004). Further, US executive pay for top managerial positions is considerably higher than that of their counterparts abroad, reflecting the 
American belief that successful people should display their accomplishment through material gain (Monk and Minow, 2004, p. 341).

However, there has been a reaction to the "one-man" dominance of the American corporation. Certain US States, such as Pennsylvania and Connecticut, have limited the singular control of the $\mathrm{CEO} /$ chair/president by adopting corporate laws similar to Germany, Japan and Canada which recognise, to varying extent, the director's duty is to take into account non-shareholder corporate stakeholders. However, more than 50 per cent of US publicly listed companies and more than 60 per cent of the Fortune 500 companies are registered under a Delaware statute that holds that directors are required to own an "unyielding" duty to the corporation and its shareholders and, by implication, few others (Greenfield, 2004, p. 105).

In fact, the role duality of chairman/CEO/president reflects the political governance model of the American President, who can choose his Cabinet from non elected members and where Cabinet members basically serve at the President's favour, though they are required to be ratified by the Congress (similar to directors being ratified by a body of shareholders).

Despite the US influence across the globe, the governance model of role duality is under attack. Research and deliberation has shown that:

- among the six principal symptoms for corporate collapse highlighted by Argenti (1976), the "one man rule" or combined chairman/CEO/president role, tops the list; others being non participative boards, unbalanced management top teams, lack of management depth and weak finance functions;

- corporate scandals and cases of executive folly are on the increase, with the chairman/CEO/president identified as being at the centre of so-called wrongdoing (Beasley et al., 1999; Charan and Useem, 2002);

- pressure from the Blue Ribbon Committee (Debman, 2002) continues for the dividing of the chairman/CEO role into two positions. Proposed is that the role of non executive chair be given to an independent, non executive director having the authority to determine both the board agenda and the quality and flow of information to the board; and

- scholars have repeatedly argued that role duality creates a structural impediment to the transparency and independence of non executive (external) directors (Pearce and Zahra, 1991; Daily and Dalton, 1994; Beasley, 1996; Slatter and Lovett, 1999; Monk and Minow, 2004).

In response to further corporate scandal, regulatory adjustment was introduced in the form of the Sarbanes-Oxley (2002), which avoided tackling the issue of role duality (Andert, 2005) but instead Sarbanes-Oxley (2002) introduced legal culpability for the falsification of information by senior corporate officers. Also accentuated under Sarbanes-Oxley was the importance of the nominations committee to counter balance the power of the chairperson/CEO.

Possibly due to role duality but also due to its limited remunerative potential, chairmanship in the USA holds a less prestigious status than that of the CEO (Coombes and Wong, 2004). The less demanding, relatively poorly paid role of part-time chairman is identified as less appealing to the highly successful US executive, even on their retirement, in comparison to their full-time managerial role (Coombes and Wong,
Demographics effects on role

pursuit

177 
$\mathrm{JMD}$

26,2

178
2004). More common is for top US executives to accept public-service responsibilities on or close to their retirement, thus further limiting the motivation to separate the roles and attract candidates for chairman who are active, full-time or part-time executive professionals (Coombes and Wong, 2004).

Conscious of the critique of role duality, a number of empirical studies have sought to test the effect of role combination against financial and non-financial performance indicators. The emerging picture, however, is inconclusive (Daily and Dalton, 1997; Dalton et al., 1998). Certain studies highlight that powerful, independently minded boards are more progressive and are associated with superior financial performance than boards dominated by the one chairman/CEO/president (Pearce and Zahra, 1991). Other studies (Dalton et al., 2003; Kakabadse and Kakabadse, 2004) conclude that board configuration is no panacea for board effectiveness. Further, recent scandals have revealed that companies with separate and combined roles have failed to be diligent with their oversight function (Kakabadse et al., 2006). On balance, however, Coombes and Wong (2004) consider the argument for separating the roles of CEO and chairman as more persuasive. Through role separation, boards are given a structural basis for acting independently and for nurturing an environment which will allow the chairman and other board members to challenge the CEO without fear of giving (or attracting) offence (Coombes and Wong, 2004).

Yet despite recent research, a paucity of insight of the consequences of continuing with the chairman/CEO role duality, particularly in terms of corporate performance and sustainability, exists (Stewart, 1991). Most of the studies pursued have been quantitative in nature, extracted from data sets rather than from observation and interaction with in-situ boardroom directors, with the results being "bound to be equivocal because the effectiveness of a particular board depends not only on composition and structure but also on the will and skill of individual board members and the interpersonal and group processes through which their energies are combined" (Roberts, 2002, p. 496).

Irrespective of the need for further knowledge, increased pressure from shareholders in the wake of public scandal has pressured US boards to introduce the role of "lead director" to act as the go-between between the chairman/CEO/president and the other board directors, to consult with the chairman/CEO/president on the drafting of the board agenda, to provide independent challenge, to consult with the chairman/CEO/president on the selection of the board committee members and sub-committee chairpersons, to ensure for adequacy of information directors receive and to directly contribute to improving the effectiveness of board meetings. Recent trends indicate that approximately 30 per cent of the largest US enterprises now have a lead director on their board (Coombes and Wong, 2004). Defenders of role duality argue that the "lead director" model, combined with other measures such as requiring boards to have a majority of independent directors and that they hold meetings without the presence of management, obviates the need for the separation of roles (Coombes and Wong, 2004).

\section{The study}

Conscious of the growing importance of the role of chairman in the UK and Australia and of the emerging pressures to "better" balance US boards, a comparative, international study of the national configurational demographics that could affect the 
role identity, performance and contribution of the chairman, was undertaken. As the study was exploratory in nature, a qualitative methodology was adopted through in-depth interviews and workshop exploratory sessions with 103 chairmen of UK, US and Australian listed companies (Table III).

Many of the study participants held more than one board role such as being chairman of one board, CEO to another organisation or non executive director (NED) and/or lead independent director (LID) of an additional board. Considering that the purpose of the interview was to understand the chairman's role and contribution from the role incumbent's perspective, "the validity, mindfulness and insights generated ... have more to do with the information-richness of the cases selected and the observational/analytical capabilities of the researcher than with the sample size" (Patton, 2002, p. 185).

In order to gain consistency across interviews, the framework of role theory (Katz and Kahn, 1966) was adopted in order to understand each incumbent's role related expectations, their interactions with and degree of influence over other board members and wider stakeholders and how such experiences helped them shape their board role. The interviews ranged from one to two hours, the majority conducted in-situ, namely the study respondent's work place. A series of common but open-ended themes were pursued allowing each respondent to uniquely position their line of response. The approach allowed for commonality of response across interviews while encouraging expansion into issues each interviewee considered important. Interviews were carried out throughout 2005 and the first half of 2006. The researchers adopted the philosophy of iterative development, devoting time after each interview to discuss its content and identify emergent critical themes to be explored in future encounters (Glaser and Strauss, 1967). Interviews were fully transcribed and additionally independently read with the objective of identifying common themes across the narratives (Riessman, 1993).

\section{Study findings}

Nine demographic determinants were identified as effecting the discharge of the role and responsibilities of chairman across the three samples, namely role boundary, executive or non executive status, accountability spread, the driving of the vision, the recruitment of chairmen, geographic domicile, counter balancing influence to that of the chairman, tenure and governance application (Table IV).

All participants concurred that the role of chairman is of critical importance to board and enterprise effectiveness, particularly so with the UK and Australian respondents. US respondents agreed, but all but one declared themselves in support of role duality, emphasising their capacity to apply different skills and capabilities when acting as CEO as opposed to being chairman of the board.

\begin{tabular}{|c|c|c|c|c|}
\hline Boardroom role & UK (FTSE 150) & USA (S \& P 500) & Australia (ASX 50) & \\
\hline Chairman & 35 & - & 33 & Table III. \\
\hline CEO/chairman & - & 35 & - & Data source \\
\hline
\end{tabular}

Demographics effects on role pursuit

179

$$
\text { acting as CEO as opposed to being chairman of the board. }
$$


JMD

26,2

180

\begin{tabular}{lll}
\hline Demographics & UK & USA \\
\hline Role boundary & $\begin{array}{l}\text { Chairman runs board; } \\
\text { CEO leads the } \\
\text { enterprise }\end{array}$ & $\begin{array}{l}\text { CEO/chair leads the } \\
\text { enterprise and the } \\
\text { board }\end{array}$
\end{tabular}

Status: executive or non-executive

Counter balancing role

Table IV. Role of chairman: demographic identity determinants
Accountability

Vision ownership

Recruitment

Domicile

Senior independent director (SID)

Tenure

Little difference in Executive dominant

practice

Chairman accountable

for board performance

Chairman: vision

passive

International

Not relevant

More effective longer in role (12 to 15 years)

Governance application compliant

\section{$\mathrm{CEO} /$ chairman} accountable for board and business performance $\mathrm{CEO} /$ chairman: vision active - if role split, then passive National Not relevant if role is split, otherwise $\mathrm{CEO} /$ chairman resides in the same city as headquarters Lead independent director (LID)
Australia

Chairman role delineation jointly determined with CEO/MD

Extensive difference

Chairman accountable for board and business performance

Chairman: vision active

National

Chair resides in same city as headquarters

Deputy chairman (n.b. little need for the counter balance)

More effective longer in More effective longer in role (eight to ten years) role (12 to 15 years)

\section{Role boundary}

The role of chairman was initially reported as "uniquely" enacted by each incumbent and adapted to each boardroom context. Board context was reported as influenced by:

- the board's history and culture;

- the norms of conduct within the enterprise;

- the pattern of selection to the job;

- the nature of socialisation with board colleagues;

- the degree to which each board member's expectations of their role was realised (or not);

- the quality of dialogue on the board;

- the nature of board power based relations; and

- external conditions such as the influence of regulators, legislation, codes of practice, stock exchange conditions and the demands of institutional investors.

Thus, the chairman's contribution was described as individually and idiosyncratically enacted from board to board and from country to country:

Look, at the end of the day I decide how I wish to run my board (UK Chairman, Utilities Company). 
More legislation; more demands, greater responsibilities but as chairman, it is up to me to have the board I want and the chief executive that I feel is right for the business (Australian Chairman, Banking Organisation).

Yes, Sarbanes-Oxley has had a substantial effect; for a start it's expensive but I made it happen. But irrespective of all that, I am the chairman I want to be. My greatest concern is to make sure that I carry the board with me! Being chairman and CEO, to have your board go against you causes real problems (USA Chairman/CEO/President, Insurance Company).

Despite the distinctly personal and idiosyncratic approach toward chairmanship, through probing, an underlying pattern was determined according to role delineation. UK chairmen more reported themselves as focusing on board affairs, leaving the CEO to run the enterprise. Intervention would only arise if it became evident that the CEO was seen to be "performing poorly".

In contrast, US chairmen determined the nature of the separation of activities allocated to the role of $\mathrm{CEO}$ and chair. Few reported that they discussed the allocation and manner of role division with their board members. However, a minority stated that they made time for board members to examine issues without the presence of any executive manager, including that of themselves, when in the role of CEO. Therefore, either at the end of, or at the beginning of, board meetings, non-executive and independent directors were allocated time on their own to discuss pertinent issues. In effect, for a minority of cases, the chairman/CEO left the room for the other board members to continue debate.

Australian chairmen emerged as more dominant than their UK counterparts with the majority reporting that they, together with their CEO or in many cases the managing director $(\mathrm{MD})$, jointly determined the nature of role delineation.

\section{Executive/non-executive status}

As much driven by a desire to have the CEO as the pivotal point of the enterprise and to be supportive of management, UK chairmen reported little difference in the role of executive and non-executive chairman. The respondents indicated that the real difference was between being a part-time or full-time chairman. All of the executive chairmen in the sample emphasised the limited number of executive functions for which they were accountable (if any). Whether executive or non-executive, the principal involvement remained with attending to the duties of board. Hence, the real difference was the level of involvement in the affairs of the board and that of the firm. Full-time chairmen reported themselves as more involved in the day-to-day affairs of the firm, whereas part-time chairmen reported greater reliance on the quality of relationship and level of trust with their $\mathrm{CEO}$ while having no executive functions reporting to them:

There is little difference between an executive and non executive chairman. The real difference is between being full-time and part-time. At the end of the day, the business reports to the CEO who reports to me. He runs the business. I look after the board and if necessary we (chair and board) sack the CEO and appoint the successor. (UK Chairman, Transport Company)

In terms of executive and non executive identity, the contrast between UK and Australian chairmen was substantial. A greater number of Australian respondents
Demographics effects on role pursuit

181 
$\mathrm{JMD}$

26,2

reported themselves as holding executive chairman responsibilities, in many cases subsuming the role of CEO. The range of executive responsibilities adopted by Australian chairmen was greater than that of their UK counterparts. A greater number of executive functions were identified in interview as directly reporting to the Australian chairman. As a result, the role of CEO in Australian companies was described as more akin to that of a managing director (MD) or even that of chief operating officer (COO), but termed $\mathrm{MD}$ :

There is a hell of a difference between being executive and non executive chairman. I am an executive chairman and quite a few of the key functions report to me. I have an MD not a CEO who, if I am honest, is more of a COO (chief operating officer). Most Australians do not understand this quaint British thing of "exec and non exec" chairs being more or less the same thing (Australian Chairman, International Food Company).

In the USA, the executive/non executive distinction did not emerge as a consideration due to role duality. What was reported as critical was being mindful of the requirements of Sarbanes-Oxley, that responsibility particularly falling on the shoulders of the CEO and chief financial officer (CFO). Attention to due process and ensuring for governance transparency was viewed as fundamental, although a sizeable proportion of US respondents emerged as critical of Sarbanes-Oxley:

I think Sarbanes-Oxley was an over reaction and it will take some time for the dust to settle. As far as my company is concerned, we are a typical board where chairman, president and CEO are all one guy - me - who has to stand before a range of 14 external directors and basically explain how he takes sole responsibility as the company's decision maker. With my future always on the line, I will tell you what I will do as chairman of the board and I don't need Sarbanes-Oxley to tell me that Chairman, US Defence Company.

\section{Accountability spread}

The executive/non-executive orientation to the role of chairman reflected in the nature and spread of accountabilities across the three samples. UK respondents reported that the chairman is held accountable for the board, its decisions, activities and performance. In contrast, the chairman/CEO of US companies and the chairman of Australian companies reported themselves as being held accountable for both board and firm performance, thus having, for some, a number of executive functions reporting to them.

\section{Vision}

Due to the accountability spread of the role of chairman, further differences emerged across the three sample groups. In terms of identifying and promoting a vision for the future of the firm, British chairmen reported their role as positioning the board to debate, challenge and "sign off" on the vision of the CEO and his/her management team. The "more passive" UK chairman was contrasted by the "more proactive" Australian chairman who reported distinct involvement in, and for some outright determination of, the vision of the company. The majority of Australian chairmen reported themselves as the "stewards" of the vision of the enterprise:

I, together with the management, set the parameters for the vision and drive that process through. I, like so many other Australian chairmen, act as the long-term anchor for the company. Our top positions (CEO/MD) are often filled from outside Australia, mainly 
Americans, and whether British or American, most of our CEOs and MDs leave after three to five years. Therefore, I need to be the one to set the vision. As it is, I am the one that is here for the long-term (Australian Chairman, Australian Manufacturing)

The CEO with his management team determines the vision and I and the board do the "reality check". If that does not survive board debate, back it goes for the CEO and the team to revise. However from my experience that is rare as we would have been discussing (CEO/chair with board) the shape of the vision in any case (UK Chairman, Energy Company).

The US respondents confirmed that the responsibility for the determination and the driving forward of the vision was theirs. However, a number raised the issue of ownership and dependency. Being the person shaping the strategic profile of the enterprise, it is all too easy for others to look for direction from the chair/CEO, thus becoming dependent and not offering constructive challenge. Additionally, lack of meaningful involvement from either the management team or the board could induce little ownership for the vision that is generated. Thus, most respondents referred to the delicate balance of "acting" as CEO while in the role of CEO and adopting a different style as chairman of the board:

It is difficult being both CEO and board chairman, especially when under pressure or when fatigued. Although I try, and try hard, I do not always become more conciliatory as chairman of the board (US Chair/CEO/President, International Commodities Company).

\section{Recruitment}

Not only the determination of the vision but also the practice of recruiting the chairman, was identified as different across the three groups. Particularly in Australia, the study participants emphasised that stringent effort was made to appoint "home grown talent" in order to ensure for long-term stability. As the Australian chairman of the manufacturing company quoted above states, a common perception is that "better" senior management talent is located off shore. Australian chairmen highlighted that the average period of tenure for, particularly American, but also British senior managers, was three to five years. Thus, Australian chairmen saw themselves as "the anchor" providing sustainability.

It is to do with taxation with the US executives we bring over. In America, with an absence of five years, all your assets are taxed globally. So with the Americans, they either become Australian citizens or go back and, guess what, back they go. I am the anchor. I keep the company together over the long-term. I have to be Australian (Australian Chairman, Services Company).

For different reasons, a similar practice was reported by US respondents. Role duality was highlighted as requiring a "hands on" approach to both the management of the enterprise and the leadership of the board. In terms of skill set, preference was given to executive track record, executive experience and managerial skills over boardroom capability. Consequently, most US chairmen reported distinctly favouring US centric executives who have the understanding, insight and sector background relevant to US based home markets:

Understanding the sector and knowing the US market is vital (US Chairman, IT Company).
Demographics effects on role pursuit 
$\mathrm{JMD}$

26,2

184

It was the British chairmen who reported a broader, international reach in terms of recruitment practice. Proximity to Europe and to the USA and the drive for penetration of non home based markets was seen to require the firm's top executives to display international skill and experience. Therefore, for both CEO and chair roles, the search parameters were broad encompassing track record, breadth of experience, international exposure, sectoral knowledge and particularly personal leadership capability. It was the British who more emphasised the leadership capacity of the individual as against other factors such as knowledge of home markets:

Being British means being international. Our reach is principally northern hemisphere. Also we are probably one of the most open markets in the world. That means the search for talent has no boundaries (UK Chairman, Investment Company).

\section{Domicile}

Mindful of their executive accountabilities and consequently being needful to attend to operational details, Australian chairmen reported that it was common practice for the chair to reside in the same city as the headquarters of the company. For the majority of US firms, the CEO element of the dual role determined that the chairman remained geographically close to the headquarters of the firm.

As far as British chairmen were concerned, the domicile of the chairmen was not considered a concern. A substantial number of British respondents reported being chairmen of British, US and Continental European companies. Travelling considerable distances to board meetings and accompanying the CEO on international tours on behalf of the firm, was reported as "part and parcel of the job".

\section{Counter balancing role}

Differences of substance not only concerned the range of activities and responsibilities of the role of chairman but also of the counter balancing influence to the chairman of the board. Partly driven by fear of further scandal but also by the realisation that the central role of chairman allows for potential domination of the board, all three sample groups reported an additional role being available for providing a counter balancing influence to that of the chairman. The role of senior independent director (SID) on UK boards is paralleled by an equally deliberately crafted role on US boards, that of lead independent director (LID). No specifically determined role such as that of SID or LID was reported as designed for Australian boards. Through default, the single source of counter argument to the Australian chairman was expected from the deputy chairman. However, not all Australian boards reported they constituted the role of deputy chairman, some viewing the position as unnecessary and others declaring already robust debate on the board.

The emerging opinion across the three sample groups was that the role of "independent" director had only recently been introduced and, as such, it was too early to ascertain the effectiveness of the SIDs or LIDs. Yet despite recent introduction, certain chairmen reported the role of independent director as offering a valuable contribution to board dynamics and board functioning. Emphasised was the importance of selecting the "right" candidate to the job. Particular chairmen described the difficulties of balancing the tension of leading the board and being attentive to the management of the firm, while nurturing a cohesive but challenging working 
environment. Unable to work on "two fronts", the value of the independent director was described as "evident".

Whether in favour of the independent director concept or not, the need for challenge within the boardroom was acknowledged. Most recognised the potential for "group think" both on boards and on the top team. Thus, the contribution of the lead/independent director was considered as influenced by cultural characteristics, whether of a national nature or more specifically the culture of a particular board. British respondents considered that the views and positions adapted by the CEO and chairman were overtly challenged within the boardroom or within informal cliques prior to board meetings, which acted as preparation for an organised confrontation at the formal meeting. In the words of one UK chairman, "British NEDs offer quiet defiance":

Yes, there have been quite a few occasions when I and others should have spoken up. But after a while something does come out, either from behind the scenes or upfront. You see, the reason we don't need SIDs is that in Britain, a NED is there to challenge at the committee meetings as well as on the main board. Sometimes a bit untidily, but challenge does come. That's your job, if not, resign (UK NED, Energy Company).

The predominant view expressed by US NED/independent directors (not so much US chairmen) was that of inhibition at board meetings. Challenging the chairman/CEO was reported as uncomfortable and unwelcome. A substantial proportion of US NED/independent director respondents reported that no matter how appropriate or timely the challenge, the level of discomfort experienced by the other board members created "an atmosphere" inhibitive of further discussion. Thus, most US board directors reported that their skills and experience were considerably under utilised. Only "favoured" directors were "offered" sufficient airtime to express their views:

You need to be someone famous to get listened to on this board. It's all down to the personality of the president/CEO/chair (US Independent Director, Pharmaceutical Company).

The reported experience of the Australian NED was that of "rugged conformism". Emphasised was the importance of teamwork and, as board, working together as a cohesive group. However, further exploration highlighted an unwillingness by individual board members to offer contrary opinion to the group's (board directors) shared mindset. In fact, one Australian NED linked teamwork with conformism. She made her views public by suggesting to the Australian Institute of Company Directors (AICD) that they cease, "teaching teamwork on boards and instead emphasise that boards are representative forums where criticism and comment concerning the future of the firm should be made while maintaining commitment to the board and the company's vision." This female board director was seen as outspoken by her peers. A minority of Australian respondents agreed with her equating teamwork on boards with "group think" which in their opinion was symptomatic of "no desire" to change. However, the majority held the opposite view, linking board cohesion with effective team relations:

We are all about teamwork and we have a really good team on this board. In fact, my number one criteria for a new board member is will they fit into this team? (Australian Chairman, Securities Company, making a public presentation to chairmen and non executive board members).
Demographics effects on role pursuit

185 
JMD

26,2

186

\section{Tenure}

Despite differences concerning the style and contribution of NEDs and independent directors and executive and non-executive chairmen (whether individually, board or nationally determined), unanimity of opinion emerged across the three groups concerning the effect of one demographic factor on chair and board performance, namely tenure. Those chairmen and board members who considered themselves, and, in turn, were also considered by their board colleagues, as holding "deep" insight concerning the value advantage of the firm, its strengths and weaknesses and why the firm was differentiated against competitors (or not), had been involved with the affairs of the company and its board for a considerable period of time. Further, UK and Australian companies which consistently exhibited higher than expected levels of performance and whose chairmen and NEDs reported their boards as high performing, attributed such continued success to being in role for between 12 to 15 years. US chairmen and board members considered length of tenure equally necessary to make a consistent difference to the performance of the board and the firm. US respondents quoted eight to ten years as the necessary period to make a significant impact on the board of US companies:

"Do you know how long the chairman and I have worked together? Well, so far, 11 years and we and the board and the business are simply getting better and better." (A point of view confirmed by the chairman and an NED of the same board) (UK CEO, Tobacco Company).

Certain respondents admitted that they broke "every governance rule in the book" (US chairman) concerning role related tenure. For UK board members, time was considered as important in order to evolve an intimacy of relationship with executive management. UK chairmen encouraged the forming, and NEDs in particular reported being encouraged to form, "buddying" type relationships with senior and functionally specialist managers in the company in areas as health and safety, the environment, corporate reputation, supply chain, etc. Buddying emerged as less popular with US and Australian chairmen. However, all the respondents across the three sample groups strongly emphasised that the longer board members worked together, the more meaningful their relationships became and the greater their understanding of the organisation and its strength, weaknesses and idiosyncrasies, the greater the opportunity for the chairman and CEO to evolve a shared mindset concerning the vision for the future of the organisation. By being together longer, success bred success. The more successful the business, the more effectively rated was the board by its members and by full-time management. Further, a longer term developed intimacy of relationship was considered as enhancing of robustness of conversation. Many described the assertive, and at times uncompromising, conversations that took place where pertinent issues were raised but in such a manner that the relationships were maintained as "professional and workable":

I almost enjoy having broken the governance rules. Me and the MD have known each other for ages. We get on well. We understand each other. The relationship is now more open than ever and, in turn, so are the board and the management. It is crazy to get people to leave when they have just really got to know each other and their job (Australian Executive Chairman, Food Products Company).

Across the three groups, it was considered the chairman's responsibility to nurture a culture which held as central the dynamic of "speak your mind whilst being mindful of 
others". Despite recognising length of tenure as advantageous, US chairmen particularly discouraged board members forming a deeper relationship with the managers of the firm. Conscious of Sarbanes-Oxley and "being seen to corrupt" the independence of board members, US chairmen admitted their setting limits to interaction between the professional management and the board:

I try really hard to be chairman of the board and then separately CEO of the company, even though I hold both positions. On the board, I make it my job for all to say anything they want and one way I do that is to visit, at least once a year, each of the independent/non executive directors on their home turf and listen to what they say. They feel better, I feel better. Overtime, we have developed a healthy respect for each other and most of all, an open style. Making the effort to see them and time spent together have been invaluable to making this board work well (US Chairman/CEO/President, Insurance Company).

I know the board would really like to get to know our managers better but with the current climate on governance, audit and regulation as it is, I thought it best to keep the two separate (US Chairman/CEO/President, Healthcare Company).

\section{Governance pursuit}

Irrespective of the source of governance imperative, such as legislation, voluntary codes, stock exchange listing requirements, the topic of governance induced two principal responses from the study respondents, "doing it in any case but not making a big deal of it", and "what an unproductive use of time but doing it in any case". "It" refers to governance application in terms of the adoption of particular processes, disciplines and protocols. Those chairmen and NED/independent directors who viewed their board and company as high performing (a perspective also supported by relevant others), remarked that recommended or obligatory governance principles were already being proactively applied - so nothing new! The push, at a national level, to transparently adopt particular disciplines of governance was already "underway" in the company, thus emphasising the pursuit of best practice. However, most complained of the cost of adopting latest governance disciplines to the letter of the "law".

For the remainder, who were the majority, governance was viewed as an expensive irritant that would only introduce minimal improvement to the "true" governance challenges the company faced. Many chairmen and NEDs in this group admitted that governance (or the lack of it) was not the problem. What was, was poor leadership and as a consequence, dysfunctional dynamics at board level and top team level. Those who admitted to dysfunctionality of both leadership and board and management relationships also admitted that both board members and the senior managers of the firm were fully aware of such concerns, as they were of their effect on the board and the firm as a whole. Many confirmed that the level of dysfunctionality, despite all other urges to act, created such discomfort that board members and even senior managers became "paralysed". The situation described was of "knowing what to do, knowing what would happen if no action took place and still doing nothing" (US Independent Director):

The relationship between the $\mathrm{CEO}$ and chair is bad and has been for sometime. You tell me how Higgs or any other code is going to sort out two emotional egoists (chairman and CEO) who want their own way, frighten everybody, but in their own way are brilliant but not when they are together. They are progressively damaging the company
Demographics effects on role pursuit 
$\mathrm{JMD}$

26,2

188

but nothing is visible on any one day. Never mind governance, we need a good SID and that is the last thing we are going to get whilst these two are around (UK NED, Energy Company).

Many of the respondents raised the question, "so how will governance sort out a problem of leadership?" Certain US respondents considered Sarbanes-Oxley to be a negative influence on board functioning. Certain admitted to a tick box mentality being even more encouraged and driving corrupt practice ever more underground due to the fact that governance procedures were adhered to but no real changes were forthcoming. Due to having to visibly act, the suspicion of wrongdoing would not be raised, with each board member justifiably claiming that they were not in possession of evidence for further enquiry at the time of governance audit:

Things are bad here. We just don't say what we should. On top of that, Sarbanes-Oxley is being applied and nothing is really going to happen. In fact, one of the board members said something to me the other day and I said - can you prove it? - if not, I don't want to know. I know that is not the right attitude but I have my reputation to protect. I am not unusual and for so many of us we recognise Sarbanes-Oxley is going to drive corruption even more underground. It will take years to dig out. Bad leadership is not solved by governance regulation. You need an equally strong leader to challenge the status quo (US Independent Director, Property Company).

\section{Conclusion}

The breadth of discretion available to each incumbent to determine the nature of the role of chairman emerged from this study as extensive. In fact, the researchers involved admitted to initially finding it difficult to ascertain common themes across interviews. For them, the early stages of the research was experienced as tracking the idiosyncratic nature of each chairman. Additional to its breadth of scope and irrespective of the level of remuneration, the role of chairman is confirmed as influential and powerful in shaping the board, directly (or indirectly) determining the strategy of the firm and in nurturing a more proactive and enabling or dysfunctional "culture" within the enterprise.

It was not until the study took on an international dimension that it became clear that individual board and firm context, in themselves, are not sufficiently influential demographics to determine chairman role, configuration and behaviour. At the national level, demographic determinates significantly emerged as effecting the role boundaries and orientation of chairmen. Geographic particulars, such as knowledge of home markets, ex patriot recruitment, the nature of governance stipulation (voluntary or legislative), role separation or duality and preference for executive on non-executive status, significantly affected board dynamics, the nature of the chairman/CEO relationship and ultimately the effectiveness of the board and the firm.

Additional to the particulars of practice within countries, the influence of "the leader", namely the individual, irrespective of the role held was recognised as the ultimate driving force of the firm. Whoever that leader is, still the leader was reported as the critical factor in determining firm success. Irrespective of governance practice and role separation or duality, one person was seen to determine the success or failure of the enterprise. Those considered to have positive effect displayed a range of styles and approaches, best suited to the business challenges facing the company. Those who 
consistently fostered dysfunctionality had one style - my way only - and one feature of personality - my way only! The study results highlight that the influence of that one man/woman can so predominate that governance becomes of secondary concern.

Thus, despite nationally determined practices, despite role delineation (or not) and sound governance application (or not), the values, qualities and behaviour of the leader(s) emerge as a key ingredient to determining firm success. So why the attention to boards and the role of chairman? It was the Ancient Greeks who defined governance in the form of a person, namely, the Kyvernitis - the oarsman or helmsman of the ship who guides the vessel through calms and storms. The term survives today. In Modern Greek, the term for government is Kyvernisi. What has not survived, however, is the duality of the leader (the helmsman), namely their influence and also adoption of the necessary disciplines for guiding the vessel or today's modern equivalent, the firm, through a "storm". As the US independent director declared, "how can Sarbanes sort out problems of dysfunctional leadership?"

Well, one response has been to introduce impersonal governance protocols to provide boundaries and controls to the actions and influence of the leaders of the enterprise. But what of the other side, the personal side? The results of the survey reported in this chapter emphasise that the modern day Kyvernitis is the chairman. The chairman is the bridge between the management and the audit, overseeing and controlling body of the firm, namely the board. Whatever else, the chairman determines governance pursuit, drives the board but also is increasingly influential in setting the cultural tone of the organisation. In effect, the chairman's influence (as a person) parallels their adoption of governance protocols. It is no surprise, therefore, to discover that those companies considered successful are better led and display sound governance. The converse seems to be a truism that those companies poorly led pay lip service to governance practice. The combination of effective leadership and governance protocol application distinguish the better run company. Perhaps one of the more sensitive challenges to face is the changing of the leader(s). In the better run and better performing enterprise, it is the chairman (or in the USA, the board) that discusses poor performing CEOs and determines the appointment of their successor. In reality, it is the chairman, less so the board, who determines the nature of CEO performance and either supports or ensures the CEO's departure.

The duality of governance (person and protocol) is back in the form of the chairman, a role that is now concluded to hold equal stature to that of the $\mathrm{CEO}$ and increasingly so in the USA.

\section{References}

Andert, D.M. (2005), "Independent directors, knowledge symmetry and all powers for enhancing board performance”, Corporate Governance: International Journal, Vol. 5 No. 2, pp. 20-2.

Argenti, J. (1976), Corporate Collapse: The Causes and Symptoms, McGraw-Hill, London.

Austin, D.V. (2005), "The sparkplug of governance, your bank's chairman, American Bankers Association”, ABA Banking Journal, Vol. 97 No. 4, pp. 18-22.

Australian Shareholders' Association Ltd ( ASA) (2004), "Corporate governance statement", available at: www.asa.asn.au/Corporate/CorporateGovernanceStatement.pdf (accessed 20 December 2004).
Demographics effects on role pursuit

189 
$\mathrm{JMD}$

26,2

190

Beasley, M.S. (1996), "An empirical analysis of the relation between board of director composition and financial statement fraud", The Accounting Review, Vol. 71 No. 4, pp. 443-65.

Beasley, M.S., Carcello, J.V. and Hermanson, D.R. (1999), Fraudulent Financial Reporting: 1987-1997. An Analysis of U.S. Public Companies, available at: www.coso.org/ publications/FFR_1987_1997.PDF (accessed 7 April 2006).

Berle, A.A. and Means, G.C. (1932), The Modern Corporation and Private Property, Macmillan, New York, NY.

Bosch, H. (1995), Corporate Practices and Conduct, 3rd ed., Pitman Publishing, Melbourne.

Cadbury, A. (1992), Report of the Committee on the Financial Aspects of Corporate Governance, Gee and Co., London.

Charan, R. and Useem, J. (2002), “Why companies fail”, Fortune, 27 May, pp. 47-58.

Coombes, P. and Wong, S.C-Y. (2004), "Chairman and CEO - one job or two?", The McKinsey Quarterly, Vol. 2, pp. 43-7.

Cutting, B.A. and Kouzmin, A. (1998), "The emerging patterns of power in corporate governance: a hermeneutic analysis of institutional archetyping and its capacity to improve corporate performance", paper presented at the 10th Annual International Conference of The Society for the Advancement of Socio-Economics (SASE), Vienna, July, pp. 1-22.

Cutting, B.A. and Kouzmin, A. (2004), "A synthesis of knowing and governance: making sense of organizational and governance polemics", Corporate Governance: International Journal of Business in Society, Vol. 4 No. 1, pp. 76-114.

Dahya, J. and Travlos, N.G. (2000), "Does the one man show pay? Theory and evidence on the dual CEO revisited”, European Financial Management, Vol. 6 No. 1, pp. 85-98.

Daily, C.M. and Dalton, D.R. (1994), "Corporate governance and the bankrupt firm: an empirical assessment”, Strategic Management Journal, Vol. 15 No. 8, pp. 643-54.

Daily, C.M. and Dalton, D.R. (1997), "CEO and board chair roles held jointly or separately: much ado about nothing?", The Academy of Management Executive, Vol. 11 No. 3, pp. 11-20.

Dalton, D.R., Daily, C.M., Certo, S.T. and Roengpitay, R. (2003), "Meta-analyses of financial performance and equity: fusion or confusion?", Academy of Management Journal, Vol. 46 No. 1, pp. 13-26.

Dalton, D.R., Daily, C.M., Ellstrand, A.E. and Johnson, J.L. (1998), "Meta-analytic reviews of board composition, leadership structure, and financial performance", Strategic Management Journal, Vol. 19 No. 3, pp. 269-90.

Debman, E. (2002), "The Cadbury Committee recommendations on corporate governance: a review of compliance and performance", International Journal of Management Reviews, Vol. 4 No. 4, p. 335.

DTI (2000), "Non-executive directors review: Higgs sets out agenda for change in the boardroom", available at: www.dti.gov.uk/cld/non_exec_review/pdfs/pressnotice.pdf (accessed 20 October 2004).

Dulewicz, V. and Herbert, P. (1999), "The priorities and performance of boards in UK public companies”, Corporate Governance: An International Review, Vol. 7 No. 2, pp. 178-89.

Dulewicz, V. and Herbert, P. (2004), "Does the composition and practice of boards of directors bear any relationship to the performance of their companies?", Corporate Governance, Vol. 12 No. 3, pp. 263-80.

Dumas, A. (1844/1992), The Three Musketeers, Wordsworth Editions Ltd, Ware.

Florou, A. (2005), "Top director shake-up: the link between chairman and CEO dismissal in the UK", Journal of Business Finance \& Accounting, Vol. 32 Nos 1/2, pp. 97-128.

Galacho, O. (2004), "Serial directors put under siege”, Courier-Mail (Brisbane), 23 December, p. 29. 
Garratt, B. (1999), "Developing effective directors and building dynamic boards", Long Range Planning, Vol. 32 No. 1, pp. 28-35.

Garratt, B. (2003), The Fish Rots from the Head: The Crisis in Our Boardrooms: Developing the Crucial Skills of the Competent Director, revised ed., Bookmarque Ltd, Croydon.

Gioia, D.A. and Chittipeddi, K. (1991), "Sensemaking and sensegiving in strategic change initiation”, Strategic Management Journal, Vol. 12 No. 6, pp. 433-48.

Gioia, D.A. and Thomas, J.B. (1996), "Identity, image, and issue interpretation: sensemaking during strategic change in academia”, Administrative Science Quarterly, Vol. 41 No. 3, pp. 370-403.

Glaser, B.G. and Strauss, A.L. (1967), The Discovery of Grounded Theory: Strategies for Qualitative Research, Aldine Publishing Company, Chicago, IL.

Greenfield, K. (2004), "Democracy and the dominance of Delaware in corporate law", available at: http://lsr.nellco.org/cgi/viewcontent.cgi?article $=1027 \&$ context $=$ bc/bclsfp $\quad$ (accessed 20 October 2005).

Hanson, R.C. and Song, M.H. (2000), "Managerial ownership, board structure, and the division of gains in divestitures", Journal of Corporate Finance, Vol. 6 No. 1, pp. 55-70.

Hempel, R. (1998), Committee on Corporate Governance: Final Report, Gee Publishing, London.

Higgs, D. (2003), Review of the Role and Effectiveness of Non-executive Directors, The Department of Trade and Industry, London.

Hodgson, R.C., Levinson, D.J. and Zaleznik, A. (1965), The Executive Role Constellation: An Analysis of Personality and Role Relations in Management, Harvard University, Boston, MA.

Jensen, M.C. and Meckling, W.H. (1976), "Theory of the firm: managerial behavior, agency costs, and ownership structure", Journal of Financial Economics, Vol. 3 No. 4, pp. 305-60.

Kakabadse, A. and Kakabadse, N. (1999), Essence of Leadership, Thompson Learning, London.

Kakabadse, A. and Kakabadse, N. (2001), The Geopolitics of Governance: The Impact of Contrasting Philosophies, Palgrave, Basingstoke.

Kakabadse, A., Kakabadse, N.K. and Barratt, R. (2006), "Chairman and chief executive officer (CEO): that sacred and secret relationship", Journal of Management Development, Vol. 25 No. 2, pp. 134-50.

Kakabadse, A., Ward, K., Korac-Kakabadse, N. and Bowman, C. (2001), "Role and contribution of non-executive directors", Corporate Governance: International Journal of Business in Society, Vol. 1 No. 1, pp. 4-8.

Kakabadse, N.K. and Kakabadse, A. (2004), "Editorial”, Corporate Governance: The International Journal of Business in Society, Vol. 4 No. 4, pp. 3-6.

Katz, D. and Kahn, R.L. (1966), The Social Psychology of Organizations, Wiley, New York, NY.

Kay, J. and Silbertson, A. (1995), "Corporate governance", National Institute Economic Review, Vol. 153 No. 1, pp. 84-97.

Lonergan, B.J.F. (1957), Insight - A Study of Human Understanding, Longmans, London.

Meyer, H. (2000), "Boards take on the heavy lifting", The Journal of Business Strategy, Vol. 21 No. 4, pp. 18-23.

Monk, R.A.G. and Minow, N. (2004), Corporate Governance, 3rd ed., Blackwell Publishing Ltd, Oxford.

Nicholson, G.J. and Kiel, G.C. (2004), "Breakthrough board performance: how to harness your board's intellectual capital", Corporate Governance, Vol. 4 No. 1, pp. 5-23.

NYSE Conference Board, New York Stock Exchange (2003), Independent Directors: From Resource to Oversight: Models for Corporate Governance, NYSE, New York, NY.
Demographics effects on role

pursuit

191 
$\mathrm{JMD}$

26,2

192

Organisation for Economic Co-operation and Development (OECD) (1999), OECD Principles of Corporate Governance, OECD Publications, Paris.

Parker, H. (1990), “The company chairman: his role and responsibilities", Long Range Planning, Vol. 23 No. 4, pp. 35-43.

Pass, C. (2004), "Corporate governance and the role of non-executive directors in large UK companies: an empirical study", Corporate Governance, Vol. 4 No. 2, pp. 52-63.

Patton, M.Q. (2002), Qualitative Research and Evaluation Methods, 3rd ed., Sage Publications Inc., Thousand Oaks, CA.

Pearce, J.A. II and Zahra, S.A. (1991), "The relative power of CEOs and boards of directors: associations with corporate performance", Strategic Management Journal, Vol. 12 No. 2, pp. 135-53.

Pettigrew, A.M. (1992), “On studying managerial élites”, Strategic Management Journal, Vol. 13, pp. 163-82.

Riessman, C.K. (1993), Narrative Analysis, Sage Publications, Newbury Park, CA.

Roberts, J. (2002), "Building the complementary board. The work of the plc chairman", Long Range Planning, Vol. 35 No. 5, p. 493.

Sarbanes-Oxley (2002), 'Sarbanes-Oxley Act', available at www.sarbanes-oxley.com/ (accessed 25 March 2004).

Slatter, S. and Lovett, D. (1999), Corporate Turnaround: Managing Companies in Distress, Penguin Books Ltd, Harmondsworth.

Stewart, R. (1991), "Chairman and chief executives: an exploration of their relationship", The Journal of Management Studies, Vol. 28 No. 5, pp. 511-27.

Taylor, B. (2001), "From corporate governance to corporate entrepreneurship”, Journal of Change Management, Vol. 2 No. 2, pp. 128-47.

Ward, R.D. (1996), 21st Century Corporate Board, John Wiley \& Sons Inc, New York, NY.

Weick, K.E. and Roberts, K.H. (1993), "Collective mind in organizations: heedful interrelating on flight decks", Administrative Science Quarterly, Vol. 38 No. 3, pp. 357-81.

Weir, C. and Laing, D. (2001), "Governance structures, director independence and corporate performance in the UK", European Business Review, Vol. 13 No. 2, p. 86.

Westphal, J.D. (1998), "Board games: how CEOs adapt to increases in structural board independence from management”, Administrative Science Quarterly, Vol. 43 No. 3, pp. 511-37.

Wilshire Mutual Funds (2005), "Dow Jones Wilshire 5000 Index Portfolio (formerly, the 'Wilshire 5000 index Portfolio')", available at: www.wilshirefunds.com (accessed 20 August 2005).

\section{Corresponding author}

Nada K. Kakabadse can be contacted at: nada.kakabadse@northampton.ac.uk

To purchase reprints of this article please e-mail: reprints@emeraldinsight.com Or visit our web site for further details: www.emeraldinsight.com/reprints 